夫：分化, 12, 614 ('63); 135) G. A. F. Harrison: Talanta, 9, 533 ('62); 136) A. M. Hartley, R. L. Asai: J. Am. Water Works Assoc., 52, 255 ('60); 137) D. G. Lewis: Anal. Chem., 33, $1127(' 61)$; 138) M. Fadda, U. Alamanni: Igiene Mod., 54, 232 ('61); A. A., 9, 5473 ('62); 139) E. Goldman, R. Jacobs: J. Am. Water Works Assoc., 53, 187 ('61); 140) A. Morette, D. Halot: Ann. Pharm. Franc., 18, 833 ('60); A. A., 8, 4850 ('61).

141) 並木 博：分化, 10，945('61)；142) 宮本 正俊：同上, 11, 511 ('62); 143) 宮本正俊：同上, 12, 32 ('63); 144) J. Murphy, J. P. Riley: Anal. Chim. Acta, 27, 31 ('62); 145) R. S. Robertson: J. Am. Water Works Assoc., 52,
483 ('60); 146) O. Sletten, C. M. Bach: ibid., 53, 1031 ('61); 147) 梅崎芳美：日化, 82, 856 . ('61); 148) 三角省三，樽谷俊和：分化，10，1113 ('61); 149) 梅崎芳美: 日化, 82, 847, 851, 1105. ('61)；150）岩崎岩次：分化，9，184 ('60).

151) 岩崎岩次, 新田 正: 工業用水, No. 23, 39. ('60); 同上, No. 32, 26 ('61); 152) 岩崎岩次, 新 田 正：同上, No. 32, 26 ('61); 153) W. Dožanśka, H. Czarnodolowa: Roczn. Zakt. Hig., Warsaw, 11, 313 ('60); A. A., 8, 4380 ('61); 154) W. Doźanśka: ibid., 13, 1 ('62); A. A., 9, 5480 ('62); 155) W. Doźanśka: ibid., 12, 403 ('61); A. A., 9, 1248 ('62); 156) K. Goto, T. Komatsu, T. Furukawa: Anal. Chim. Acta, 27, 331 ('62).

\title{
14 大気污染分析
}

長谷川利雄 $*$ 桜井 謙一**

近時, 大気污染問題は国の内外を問わず，社会的に大 きく取り上げられ，その抜本的対策の確立が強く要望さ れている. 欧米ではすでに関係法令が定められ，各種の 対策が実施されているが，わが国でもさる 1962 年 6 月 「ばい煙の排出の規制等に関する法律」1)が公布され，京 浜, 阪神および北九州などの主要工業地域に適用されて いる. 1963年 7 月には前記の地域指定と同時に煙道排ガ ス中のばいじん量および燃焼排ガス中の全イオウ酸化物

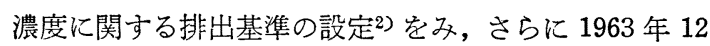
月にはスモッグ対策に関連して亜硫酸ガス濃度などの基 準3)が定められ，ばい煙や有害ガスなどの大気污染物質 の科学的測定はいよいよその重要性を増してきている.

最近における大気污染の傾向としては発ガン性物質と いわれているベンツピレンや自動車排気ガス中の炭化水 素などの有機化合物の機器による測定に関する研究報告 がかなり多く見受けられる。

本進歩総説は 1961 年から 1963 年までの間の論文を 採用したが，測定法を含めた大気污染全般にわたる一般 著書4) 10) も相当多く，またこれらについてエアロゾル， ガス分析およびフィールドサンプリングなど広範囲にわ たる総説11 15)もある.

\section{$14 \cdot 1$ 污染大気の測定}

大気中の污染物質の一般的調査やサンプリングの方法

* 大阪府商工部 : 大阪市東区大手前

** 大阪大学教養部 : 大阪府豊中市柴原

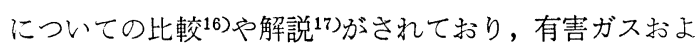
び蒸気の測定 ${ }^{18) 19)}$, 空気中の自動車排気ガスによる污染 成分の連続測定装置 ${ }^{20}$ に関する解説も行なわれている.

$\mathbf{1 4} \cdot \mathbf{1} \cdot \mathbf{1}$ サンプリング 低濃度の 3,4 -ベンツピレン の定量のため $275 \mathrm{~m}^{3} / \mathrm{hr}$ の吸引速度で $1400 \mathrm{~cm}^{2}$ のフ ィルターを使用したもの21)や工業地域におけるばいじえ の捕集ならびに測定 ${ }^{22)}$, 分解しない無機または有機物質 のサンプリングを行なうグラスファイバーフィルターの 適用範囲 ${ }^{23)}$, ガス検知管補正の基礎理論 ${ }^{24)}$, 産業衛生上 における吸着剤の効率25および大気污染測定用エアーサ ンプラーに関する研究26)などについて報告されている.

a）エアロゾル 都市大気のばいじん中の酸性物質測 定のための直径 1 インチの口紙による捕集 ${ }^{27}$ ) (吸引速度 $30 \mathrm{l} / \mathrm{min}$, 吸引時間 $6 \mathrm{hr}$ ), プリインピンジャーとカ スケードインパクターの 2 段式エアーサンプラーの設 計 ${ }^{28)}$, 新型 2 段階カスケードインパクターの考案とその. 応用29), ホリスチレンラテックスとジオクチルフタレー トを用い，0.1〜 1 $\mu$ の粒径範囲のダスト分離器によりサ ンプルを捕集してのエアロゾルスペクトロメーターとカ スケードインパクターの比較研究30)などが報告されてい る.

b） ガスおよび蒸気 化学反応工程中から発生するガ スを捕集する新装置として小型軽量サンプラーが考案さ れ(1), ハロゲン, $\mathrm{H}_{2} \mathrm{SO}_{4}, \mathrm{HNO}_{3}, \mathrm{H}_{3} \mathrm{PO}_{4}, \mathrm{Hg}$ 蒸気, ホスフェート類のダスト, $\mathrm{NH}_{4} \mathrm{Cl}, \mathrm{NH}_{4} \mathrm{NO}_{3}$ 霧, 有機 物霧などのテストに使用されている.このほか固体吸収 
剤の湿潤層を利用する大気中の有害物質の蒸気およびガ スの捕集 ${ }^{32)}$, 大気污染の連続測定のための液体精密定速 移送ポンプ33), 空気流量の連続自動定速調節器 ${ }^{34)}, 130 \sim$ $150 \mu$ の厚さの多孔性フィルターに $\mathrm{NaHCO}_{3}, \mathrm{KHCO}_{3}$, $\mathrm{Na}_{2} \mathrm{HgCl}_{4}$ を含浸させ，大気中の微量ガスを捕集なら びに測定する方法 $\left.{ }^{35}\right)\left(\mathrm{SO}_{2}\right.$ の場合は適用範囲 $0.1 \sim 10$ ppm)，またこれに類似した方法で $1 \% \mathrm{HOC}_{2} \mathrm{H}_{4}, 3 \mathrm{~N}$ の $\mathrm{KOH}, \mathrm{K}_{2} \mathrm{CO}_{3}, \mathrm{KHCO}_{3}, \mathrm{KOH}-\mathrm{K}_{2} \mathrm{HgCl}_{4}$ あるいは $\mathrm{K}_{2} \mathrm{CO}_{3}-\mathrm{K}_{2} \mathrm{HgCl}_{4}$ の水溶液で含浸された口紙 (Whatman No. 1, 径 $5.5 \mathrm{~cm}$ ) を用いて大気中の $\mathrm{SO}_{2}$ を捕 集し $98 \%$ の効率を示した報告 ${ }^{36}$ )などがある.またイン ピンジャーによる $\mathrm{SO}_{2}$ の捕集効率の検討 ${ }^{37}$ や検知管に よる空気中のベンゼン同族体の濃度測定についての信頼 度38なを゙についても述べられている。

14.1.2 ばい煙および粉じん 大気中のばい煙, 粉 じんなどに関する一般的研究報告としては, 粉じん濃度 測定の方法論39), ダス卜量測定法に関する膜口過とその 適用範囲, 粒子数の測定記録装置 ${ }^{40)}$, 大気污染測定用自 動記録インパクター41), およびばい煙濃度測定法に関す る比較研究42などがある.このほか大気中の固体微粒子 の沈降測定法の比較テスト ${ }^{43)}$, 空気およびその他のガ ス中の種々の浮遊物質の分離のためのテストフィルタ 一4), photosedimentometric 法を利用した粒度測 定45)，およびサイクロンとフィルターを組み合わせた 2 段式サンプラーを使用した呼吸粉じんの測定 ${ }^{46) な と ゙ に つ ~}$ いて述べられており，また，含じん量可変空気製造装置 を使用して試験用ダストを拡散させ，エアロゾルを発生 させる試験装置47についても報告されている。なお，大

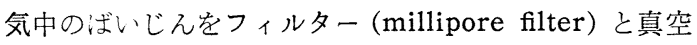
ポンプで捕集したのち，顕微鏡で粒度分布を測定する方 法 ${ }^{48)}$, および散乱光を利用したエアロゾル濃度測定の改 良装置 ${ }^{49}$ が考案され, さらに Loebner と Bergerhoff とのばいじん量測定装置の比較検討 ${ }^{50)}$, 自動粒度測定器 の性能試験 ${ }^{51)}$, 各種ばいじえ量測定器による測定值の再 現性 ${ }^{52)}$, ばいじん測定における乾式法と湿式法との差 異53), 英国規格ばいじん計と衛生試験法簡易ばいじん計 との比較テスト ${ }^{54)}$, ばいじん成分の測定 ${ }^{55565)}$, 空気中浮 遊粒子観測用写真撮影式限外顕微鏡装置の試作 ${ }^{57)}$, 光学 密度と粒子数, 粉じえ重量の相関関係を応用した口紙じ えあい計 ${ }^{58)}$, ばいじん水溶成分中の硫酸イオンの比濁定 量法59などについても述べられている. 大気中の硫酸ア ンモニウムをフィルターで吸引捕集し, 水に溶解したの ち $\mathrm{NH}_{4}+$ 濃度をネスラー試薬または $\mathrm{C}_{6} \mathrm{H}_{5} \mathrm{OH}$ と $\mathrm{NaClO}$ により分析60)する方法, 大気中の微量酸性物質の分析 ${ }^{61)}$ なども行なわれている。
金属とその化合物に関する測定法についてもかなり報 告されているので，次にそれらを列挙する. こクロンお よびセミミクロンオーダーの $\mathrm{PbO}$ 粒子の粒度測定なら びに確認についてスポットテストを応用 ${ }^{62}$ 寸する法, ダス ト中のバナジウムを発光分光分析により測定する法63), 大気中のばいじんを空気口過器で捕集後, 2,3,7-trihydroxy-9-phenyl-6-fluorone を用いてゲルマニウム

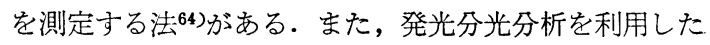
ものとしては, 大気中の微量 $\mathrm{Na}$ 測定 ${ }^{65}$ ) (精度 $0.1 \mathrm{mg}$ $\mathrm{Na} /$ 大気 $l$ ), 口紙で吸引捕集した試料中の $\mathrm{Be}$ を $\mathrm{Ag}$ 台 上にのせて直接スパークさせて行なったものがある66).

比色分析を応用したものとしては，ダスト中の $\mathrm{Zr}$ と その化合物を $\mathrm{K}_{4} \mathrm{Fe}(\mathrm{CN})_{6}$, dimethyl-aniline による 呈色反応 ${ }^{67)}$, 工業地带の大気中の $\mathrm{Zr}$ とその化合物を Arsenoazo, Na-alizarin-sulfonate, phenylfluorone, morin および quercetin と $\mathrm{Zr}^{4+}$ による呈色反応 ${ }^{63)}$, $\mathrm{Al}$ とその化合物を口紙に吸引捕集し，強熱残さを $60 \%$ 熱 $\mathrm{KOH}$ で処理し蒸発残さを水に溶解し, $\mathrm{H}_{2} \mathrm{SO}_{4}$ で中 和後 $\mathrm{pH} 4.7$ の bufferを加え $0.1 \%$ アルミノン溶液に より発色させ 1 時間後比色分析 ${ }^{69)}$, ダスト中の $\mathrm{Hg}$ を $700^{\circ} \mathrm{C}$ で 30 分間石英管内で強熱し (還元凨性鉄粉), 管中の $\mathrm{Na}_{2} \mathrm{C}_{2} \mathrm{O}_{4}$ からでる $\mathrm{CO}$ が $\mathrm{Hg}$ 蒸気を追出すこ とを利用した比色定量 ${ }^{70)}, \mathrm{Ge}$ と $\mathrm{GeO}_{2}$ を phenyl-

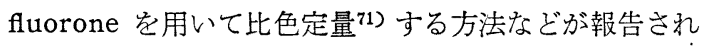
ている.

ポーラログラフを利用したものとしては, $\mathrm{Mn}^{722}$ の試 料を少量の $10 \% \mathrm{HNO}_{3}$ に溶解し, 蒸発残さを $0.1 \mathrm{~N}$ $\mathrm{HCl}$ に再溶解し, $0.1 \mathrm{~N} \mathrm{NH}_{4} \mathrm{OH}$ で $\mathrm{pH} 4$ にし $0.1 \mathrm{~N}$ $\mathrm{Na}_{2} \mathrm{SO}_{3}$ を用い増幅法で測定する. $\mathrm{Ti}$ と $\mathrm{TiO}_{2}{ }^{73}$ は $5 \% \mathrm{H}_{2} \mathrm{SO}_{4}$ に空気を通じ perchlorovinyl filter で口過 乙, 強熱残さを $\mathrm{K}_{2} \mathrm{~S}_{2} \mathrm{O}_{7}, \mathrm{H}_{2} \mathrm{SO}_{4}, \mathrm{~K}_{2} \mathrm{C}_{2} \mathrm{O}_{4}$ などで処理 する方法 ${ }^{74)}, \mathrm{Mn}, \mathrm{Cr}, \mathrm{Fe}$ は triethanolamine を用 いて測定する方法75などがある.

14.1.3 無機性ガスおよび蒸気これらに関する測 定法は次に示すようにかなり多い.

a） CO p-スルフォミド安息香酸銀アルカリ性溶液 に CO を含む気体を接触させるとその分圧に比例して 銀のゾルを生ずる.これを応用した $\mathrm{CO}_{2}$ 中の微量 $\mathrm{CO}$ の定量 ${ }^{76)}$, 微量の $\mathrm{CO}$ と $\mathrm{N}$ 酸化物の自動測定器77), 不 飽和炭化水素, 酸性ガスおよび塩基性不純物などを除去 したのち, 大気中の微量 $\mathrm{CO}$ を $\mathrm{CO}_{2}$ に酸化し, 電気伝 導度により測定するポータブル測定装置 ${ }^{(8)}, \mathrm{PdCl}_{2}$ を充 てんしたシリカゲルの新型 $\mathrm{CO}$ 検知器79)などがある.

b) $\mathrm{CO}_{2} \quad \mathrm{CO}_{2}$ はフェノールフタレインを指示薬とし て $0.005 \mathrm{~N} \mathrm{Ba}(\mathrm{OH})_{2}$ に吸収させる方法 ${ }^{80)}, \mathrm{O}_{2}, \mathrm{~N}_{2}$ その 
他の不活性気体と共存する 10 ９0\% の $\mathrm{CO}_{2}$ 自動試料 採集装置 ${ }^{81)}$, 試料を水蒸気で飽和し, これを大理石粉末 を入れた水に通し, この水の $\mathrm{pH}$ を Beckman 76 型 拡大スケール $\mathrm{pH}$ メーターで測定する簡単な $\mathrm{CO}_{2}$ 分析 器82), $\mathrm{Ba}(\mathrm{OH})_{2}$ 溶液による電導度法に代わり, 高周波

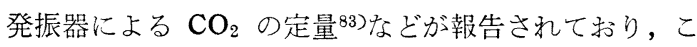
のほか, 大気中の $\mathrm{CO}_{2}$ の質量分析計による測定値に及 ぼす光の影響84)についても述べられている.

c) $\mathrm{S}$ 酸化物 生産工場の大気中の $\mathrm{SO}_{2}$ 濃度を測定 するため, 少量の $\mathrm{KIO}_{3}$ を含有した $\mathrm{K}_{2} \mathrm{Cr}_{2} \mathrm{O}_{7}$ の希薄 酸性溶液中に空気を通じ，でえ粉を指示薬とした簡易迅 速法 ${ }^{85)}$, 急速に変化する $\mathrm{SO}_{2}$ 濃度を $0.01 \sim 10 \mathrm{ppm} の$ 範囲で電導度測定により求めて記録する装置 ${ }^{86}$, 電導度 測定に基づく自動記録式連続測定装置の発達の過程, 適 用範围, ゼロ点調整, 選択性, 記録の感度なぞについて の研究 ${ }^{87}$, 低濃度の $\mathrm{SO}_{2}$ 測定装置の感度, 選択性, 移 動性などについての総説 ${ }^{88)}$, アイソトープ ${ }^{85} \mathrm{Kr}$ を用い て, quinol 中に混入した ${ }^{85} \mathrm{Kr}$ の脱離を応用した $\mathrm{SO}_{2}$ の測定 ${ }^{89)}, \mathrm{N}_{2}$ および重金属類酸化物の存在下における 大気中の $\mathrm{SO}_{2}$ の測定 ${ }^{90)}$, フィールドテストによる $\mathrm{PbO}_{2}$ 法の測定值との比較91)，大気中の $\mathrm{SO}_{2}$ とばいじん量が 場所によってはばいじえ中の 1 成分と他の成分間また は, 汭い゙んと $\mathrm{SO}_{2}$ の間にかなりの相関関係が認めら れる92)などの報告があり, また, パラローズアニリン法 を応用した微量 $\mathrm{SO}_{2}$ の迅速測定用ポータブル装置 ${ }^{93}$ ) (測 定範囲 $\left.0.025 \sim 2 \mathrm{mg} / M^{3}\right)$, ばい煙や工場排ガス中の $\mathrm{SO}_{2}$ に暴露された植物表面に付着した $\mathrm{SO}_{2}$ のポーラログラ フによる定量分析 ${ }^{94)}$, 10の区域の異なった工業地域で実 施した 22 地点における 5 種類の $\mathrm{SO}_{2}$ 測定装置の比較 研究 ${ }^{95)}, \mathrm{KOH}$ とグリセリンまたはトリエタノールアミ ンを浸せきした口紙を使用した大気中の $\mathrm{SO}_{2}$ の捕集 ${ }^{96}$, $\mathrm{K}_{2} \mathrm{CO}_{3}$ を用いて前処理したアルカリ紙による $\mathrm{S}$ 酸化物 などの定量97について述べられている.さらに, 都市大 気中のばいじんをロ過法で捕集したのち，0.01N テト ラホウ酸ナトリウム溶液（pH 7) に吸収させ, 同規定 液で pH 7 になるまで中和滴定する分析法 ${ }^{98)}$, 大気中の $\mathrm{SO}_{3}$ を測定するため, トリウムエリオクロムシアニン $\mathrm{R}$ のレーキがアセトン存在下に扔いて $\mathrm{pH} 3.5$ で $\mathrm{SO}_{4}{ }^{2-}$ により定量的にかっ色化するのを応用した方法 ${ }^{99}$ ) (妨害 物質 $\mathrm{HF}, \mathrm{H}_{3} \mathrm{PO}_{4}$ ), Glocken 变法による $\mathrm{S}$ 化合物, 塩 化物などの簡易測定法 ${ }^{100)}$ についても報告されている.

d) $\mathrm{H}_{2} \mathrm{~S}$ 酢酸鉛タイルを利用して低濃度の硫化水素 の定量 ${ }^{98}$ について $\left(\mathrm{H}_{2} \mathrm{~S}\right.$ 濃度 $\left.0.15 \sim 1.43 \mathrm{mg} / M^{3}\right)$, 野 外抢よび室内実験を行なった報告 ${ }^{101}$ ) (暴露時間 15 分〜 6.5時間), $\mathrm{Na}$-nitroprusside を $\mathrm{Na}_{2} \mathrm{CO}_{3}$ と $\mathrm{NaHCO}_{3}$
の水溶液に溶解した試薬を用いた比色分析 ${ }^{102)}, \mathrm{SO}_{2}$ と の反応などを検討した大気中の微量 $\mathrm{H}_{2} \mathrm{~S}$ の定量 ${ }^{103)}$ どが述べられている.

e） $\mathbf{N}$ 酸化物 2 光路比色計を用いて Griess Saltzman 試薬の発色を吸光光度法により 連続的に測定 ${ }^{104}$ （適用範囲 $0.02 \sim 0.5 \mathrm{ppm}$ ) する方法, 大気中の種々の $\mathrm{N}$-酸化物の測定法として, $\mathrm{NO}_{2}$ は $\mathrm{NaOH}$ 中に吸収し Griess-Ilosvay 試薬を加えて比色, $\mathrm{NO}$ は $\mathrm{KMnO}_{4}$ で 酸化し $\mathrm{NO}_{3}{ }^{-}$とし phenoldisulfonic acidを用いて比 色また $\mathrm{NO}_{3}$-は $\mathrm{Zn}$ で還元し $\mathrm{NO}_{2}$ にして定量する方 法などに関して検討105)106)されている.

f) $\mathbf{F}$ とその化合物 大気中の HF 定量については, パイレックスガラス製のアスピレーターを使用し， $\mathrm{Fe}$ $\mathrm{Cl}_{3}$ のアルコール溶液, 濃度などを改良した $\mathrm{HF}$ の比色 分析107)，試料を $0.01 \mathrm{~N} \mathrm{NaOH}$ に吸収し， Zr-alizarin 法によるFの比色 ${ }^{108)}$, Bromophenol Blue との反応 を利用した HF の迅速定量法 ${ }^{109}$ （感度 $0.0005 \mathrm{mg} \mathrm{HF} /$ $l$ air), $\mathrm{SF}_{6}, \mathrm{CCl}_{2} \mathrm{~F}_{2}, \mathrm{CCl}_{3} \mathrm{~F}$ については, ionization currentを利用した微量測定 ${ }^{110)}$ ，スペクトル分析によ る $\mathrm{F}$ と $\mathrm{F}$ 化合物の間接定量 ${ }^{111)}, \mathrm{SrF}_{2}$ の形式などを利用 した F の定量 ${ }^{112)}, \mathrm{HF}$ ガスを蒸留水に吸収するときの捕

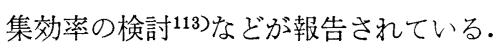

g） $\mathrm{O}_{3}$ 大気中の微量オゾンの定量法としては, 中性 リン酸緩衝溶液に低濃度の KI を溶かして空気を通じオ ゾンに酸化された $I_{2}$ をチオ硫酸滴定して定量 ${ }^{114}$ ) (測定 範囲 0.06 0.6 $\left.\mathrm{mg} \mathrm{O}_{3} / M^{3}\right)$, Olmer の方法によるもの で検出箱の中にガスを通し, その温度変化と電流によ

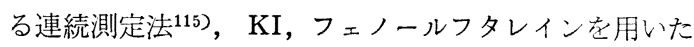
mini Adak 分析器による測定 ${ }^{116)}$, 検流計法による大気

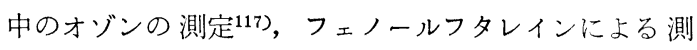

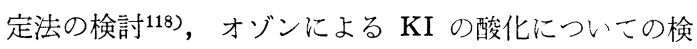
討119), oxidants を測定するフェノールフタレイン法の 変法120)などについて報告されている.

このほか, 大気中のニッケル,ニッケルカルボニルは, 口紙により捕集したのち, ジメチルグリオキシムの反応

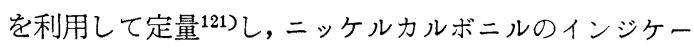
ターによる測定法122)としては, シリカゲル上で $\mathrm{AgNO}_{3}$ を黒い Ag にする方法と, molybdophosphoric acid （黄色）を heteropoly acid (濃青色) に還元する方法, また, ヨウ素-エチルアルコール溶液中に空気を通じて 生成した NiI をジメチルグリオキシムによる比色法 ${ }^{123)}$ で測定し, 大気中の $\mathrm{PH}_{3}$ は $\mathrm{AgNO}_{3}$ 含浸紙で測定 ${ }^{124)}$ 125）している.酢酸にトリクロロシランを加え, さらに 5\% モリブデン酸アンモニウム溶液を加えて標準液を調 製し，同様に空気から $\mathrm{SiHCl}_{3}$ を捕集し比色定量 ${ }^{126)}$ 
行なっている.

\section{4·1・4 有機性ガスおよび蒸気}

a）炭化水素類 ガスクロマトグラフィー（GC）に よる分析技術の発展に伴って広範囲の炭化水素の定量が 行なわれた. エンシン排気, 石炭燃焼排ガス, 野外大気 などの現場分析に十分利用できる精度で $\mathrm{C}_{2} \sim \mathrm{C}_{6}$ の炭化 水素が分離測定され， $\mathrm{CH}_{4}$ 注存する $\mathrm{CO}$ ととも酸 化後 $\mathrm{CO}_{2}$ として測定 ${ }^{127}$ された. 水素炎イオン化検出器 を用いた GC 法では低濃度の炭化水素が迅速に分析さ れ, エチレン, プロピレン, ブタン, ペンタン, ベンゼ ンなどがこの方法128) で行なわれた。そのほか低級炭化 水素の分離法としても GC 法がよく利用され，メタン とブタン，エチレンとブチレンなどの低濃度分離法が冷 却したシリカゲルに吸着させて $120^{\circ} \mathrm{C}$ で測定 ${ }^{129)}$ され た。また，エチレンは過ヨウ素酸で酸化して chromotropic acid と反応させ発色を比色測定する方法 ${ }^{130)}$, あ るいはブロム化して赤外分析と GC 法とを用いる測定 法131) が述べられている. イソブチレンの定量には比濁 法 ${ }^{132}$ )が迅速測定法として報告され, エチレン, クロロ ホルム, 塩化エチルなどの妨害もなく, 現場測定法とし て有効であると述べられている.

イソプレンは $\mathrm{Br}$ と反応させたのち, KI を添加して $\mathrm{I}$ を遊離させ $\mathrm{Na}_{2} \mathrm{~S}_{2} \mathrm{O}_{3}$ 溶液により 滴定する方法 ${ }^{133)}$ が 述べられている. そのほか, スモッグ中のオレフィンレ コーダーの検討がされた ${ }^{134)}$. スチレンには比色分析が 多く述べられている.モノクロロスチレンのm-dinitrobenzene による発色 ${ }^{135)}$, また $\mathrm{H}_{2} \mathrm{SO}_{4}$ で処理したス チレンの黄色樹脂136）の比色分析法, 酢酸水銀 および diphenylcarbazid による比色法と硫酸水銀を加えて難 溶性生成物の比濁試験 ${ }^{137)}$ などが行なわれた. $\alpha$ ーメチル スチレンは分光光度法 ${ }^{138)}$ によって分析される. 芳香族 炭化水素についても GC 法が広く応用され, 有機物蒸 気中のベンゼンの測定 ${ }^{139}$, 水素炎イオン化検出器を用い た $\mathrm{C}_{6} \sim \mathrm{C}_{11}$ 化合物の $\mathrm{GC}$ 分析法 ${ }^{140}$ が述べられた。 ベンゼンをニトロ化して比色分析を行なう方法 ${ }^{141)}$ は従 来に引き続きキシレン,トルエンなどにも応用されてい る.

ditolylmethane は直接 $\mathrm{C}_{2} \mathrm{H}_{5} \mathrm{SH}$ 溶液の 紫外部吸収 スペクトルを測定する方法や，ニトロ化して $\mathrm{Zn}$ 還元 し，これに diazo 化した $p$-nitroanilin を作用して発 色させ，可視部吸収スペクトルを測定するなど分光光度 分析法 ${ }^{142)}$ が述べられている.この方法では共存してい るスチレンによって影響は受けない. 最近, 特に重要な 問題となっている発ガン性污染物の測定に関して多環式 炭化水素の 分析測定法が多く見受けられる. 主として
$\mathrm{Al}_{2} \mathrm{O}_{3}$ カラムクロマトグラフィーで分離して紫外部吸收 スペクトルを測定する分光分析法 ${ }^{143)}$ が従来から引き続 き行なわれ 10 数種類の多還式化合物が分析されている が，測定試料の処理中で起る誤差の検討144)や，ベンゼ ン同族体の濃度測定に対する信頼度 ${ }^{145)}$ の検討も述べら れている. 特にピレン類については $\mathrm{Al}_{2} \mathrm{O}_{3}$ カラムク ロマトグラフィーで鎖式化合物と分離後 GC 法146)で定 量分析をする方法，あるいはケイ光分析法 ${ }^{147) ~ 150) ~ に よ ~}$ る定量法などが多く, benz $(\alpha)$ pyrene, anthracene,

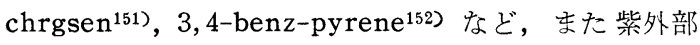
吸収スペクトル 測定による数種のピレン 誘導体の定量 法153)154)およびピペロナールテスト155), 微量昇華法によ る迅速測定法156)などが述べられている。

b） ハロゲン化合物 塩素化合物は GC 法によって 分離後, 個々の化合物について燃焼して生成した $\mathrm{HCl}$ を $\mathrm{NaOH}$ 溶液に捕集して, $\mathrm{AgNO}_{3}$ を添加, その懸濁

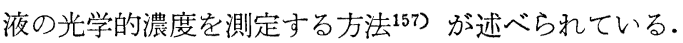
この方法では適当な吸着液を用いることによって，塩化 メチレン, クロロホルム, 四塩化炭素, tetrachloropropane, tetrachloropentane, tetrachloroheptane, tetrachlorononane などが分離定量された。 また， tetrachloroethylene は直接紫外部吸収スペクトル測 定158)で分析が行なわれた.

比色定量法も多く述べられている。たとえば，採集試 料にピリジンあるいはキノリンを加えて加温反応させて 生じる呈色を比色測定するもので, hexachloropentadiene, polychloropynene, polychlorocamfor ${ }^{159)}$, chloroethane ${ }^{160)}$, 四塩化炭素, クロロホルム, tetrachloroethylene, trichloroethylene ${ }^{161)}$ などの定量分 析法が述べられている. 臭素化合物は燃焼させて, 生成 した $\mathrm{Br}$ KI を作用させて $\mathrm{I}_{2}$ を遊離して, 滴定し定

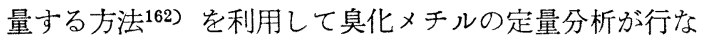
われている. また, フッ素化合物については, 採集した フッ素化合物を加水分解して $\mathrm{HF}$ とし, $\mathrm{KBr}, \mathrm{KBrO}_{3}$ を作用させて遊離した Br をエオシンカラムの検知管を 用いて分析する方法で高分子フッ素化合物の熱分解揮発 成分の定量分析例が見受けられた ${ }^{163)}$. また微量分析法 としてはアニリンとケトンとの呈色を利用した比色法 や $\mathrm{SiO}_{2}$ 上 $900^{\circ} \mathrm{C}$ で試料を通して生成した $\mathrm{SiF}_{4}$ を モリブデン酸アンモンで呈色し比色する方法などがあ り,この方法で fluoroalkylchlorosilane 化合物の定量 分析 ${ }^{164)}$ が述べられている. 赤外分光分析法も八ロゲン 化合物の分析に利用され，光路の長い吸收セルを用いる ことによって数 ppm 程度の濃度での測定が 可能である と報告されている165). 
c） アルデヒド，ケトンおよび含酸素化合物 $\mathrm{HCHO}$ の定量法は chromotropic acid との発色による比色分 析が従来に引き続き述べられている. 試料採集技術の発 達に伴ってさらに利用度の高い方法となってきた(166)167). その他のカルボニル化合物についても発色試薬と反応さ せて,比色分析を行なう方法が多く述べられている．acetophenone はエタノール溶液に吸収して $m$-dinitro-

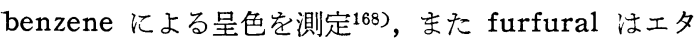
ノール-酢酸溶液に吸収させてアニリンによる呈色液の 光学的濃度の測定 ${ }^{169)}$ によって定量分析が行なわれてい る.アクロレインは直接紫外部吸収スペクトル測定によ る分析が述べられ，種々の溶媒が検討170)171)された。ま た，水素炎イオン化検知器による GC 法も利用され， benzaldehyde, benzoylchlorideなどの迅速測定法 ${ }^{172)}$ が述べられている.低濃度アルデヒド類についてボーラ ログラフィーが利用され $\mathrm{LiOH}$ をバックグラウンドと して用いて, HCHO, furfural および paraaldehyde から分解して生成した acetoaldehyde の混合物を半波 電位の 差から 分離定量分析 ${ }^{173)}$ が行なわれた。アルコ 一ル類の分析法は比色定量法が多く述べられている. ethyleneglycol は過ヨウ素酸で酸化し $\mathrm{Pb}\left(\mathrm{CH}_{3} \mathrm{COO}\right)_{2}$ を反応させて生成した HCHOを chromotropic acid の呈色を利用した分析(例174 177) が多く, ethylenechlorohydrin, ブタノールなどは $\mathrm{KMnO}_{4}$ で酸化して シュウ酸で滴定するほか，キシレンに吸収させて Vquinolinol 錯体として, とう赤色の呈色を比色する方 法178) が述べられている. そのほか, 酸性で $\mathrm{NaNO}_{2}$, $\mathrm{NH}_{2} \mathrm{OH}^{179)}$ の呈色反応， $p$-dimethylaminobenzaldehyde との縮合反応による呈色の測定 ${ }^{180}$ によって, $\mathrm{C}_{4} \sim$ $\mathrm{C}_{10}$ の直鎖アルコール類やイソブチルアルコール，イソ アミルアルコールなどの分析が行なわれている．また， この発色試薬として trimethylolpropane ${ }^{181)}$ の吸光 光度分析も報告された。 また，発色試薬として $\mathrm{NH}_{4}$ vanadate ஓ 8-quinolinol などを用いた分析法 ${ }^{182)}$ も 述べられている。そのほか, 吸収剂としてのシリカゲル の利用も報告183) された。 フェノール類は $\mathrm{K}_{3} \mathrm{Fe}(\mathrm{CN})_{6}$ を酸化剤として 4-aminoantipyrin の発色を利用した 比色分析 ${ }^{184)}$ がすぐれている。 そのほか, diazo 化 $p$ aminobenzene sulfonic acid による分析法 ${ }^{185) 186), ~ ホ ゚ ~}$ ーラログラフィーによる $o^{-}, m^{-}, p$-置換フェノール類の 分離定量法183)184)などが行なわれた. カルボン酸類は主 としてェステルに誘導して, hydroxylamine と $\mathrm{FeCl}_{3}$ による呈色を比色測定 ${ }^{187) さ れ た . ~ a c r y l i c ~ a c i d, ~ m e t a-~}$ crylic acidなどのエステル188), 酢酸, アジピン酸, フ タル酸などのエステル189) の分析法が述べられている.
またアジピン酸，フタル酸などの dibutyl ester は加水 分解して得たブタノールに $p$-nitrobenzaldehyde ある いは $p$-dimethylaminobenzaldehydeなどを反応させ て比色定量が行なわれた ${ }^{190) 191) 。 そ の ほ か, ~ t e t r a h y d r o-~}$ furan ${ }^{192)}$ 注酸分解し, $p$-dimethylaminobenzaldehyde を用いた比色分析が示されている。

d） N-化合物 アミン類の分析法としては $o$-nitrophenol を用いた比色法が示されている. 共存する $\mathrm{NH}_{3}$ 濃度は別に捕集してネスラ一法で決定し, 全アミン濃度 から差引かれる。この方法で methylamine, dimethylamine, trimethylamine, ethylamine, triethylamine などの分析例193)が示されている. 大気中のフェ ノール類やアミン類の分析には発色反応が重要であり, 安定な分析試薬としての diazonium salt の研究194) も 行なわれた.リンモリブデン酸, リンタングステン酸な どを用いた dimethylbenzylamine の比色分析法195)も 試みられているが，共存アミンの妨害が大きい。そのほ か $\mathrm{CS}_{2}$ と $\mathrm{Cu}$ 塩とによる diethylamine の比色 ${ }^{196)}$, また furfural 溶液中での発色を利用した dimethylamine の比色法197)などが見られた. dimethylformamide はアルカリ性で分解して同様の方法 ${ }^{198)}$ で分析 された. phosphoamide は diazo-p-aminobenzene sulfonic acidを用いた比色法, あるいはリンモリブデ ン酸の還元反応で生成するモリブデンブルーによる比色 法199）などが分析法として示されている．上に記した diazo 試薬は hydrazid 化合物にも利用200)された。 indol については $\mathrm{HNO}_{3}$ 酸性で $\mathrm{NaNO}_{2}$ を作用させる

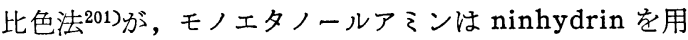
いた比色法 ${ }^{202}$ が述べられている.この際，常に $\mathrm{NH}_{3}$ の 共存が伴うから ninhydrin, $\mathrm{CaCO}_{3}, \mathrm{H}_{3} \mathrm{BO}_{4}$, を順次 ガラス管に充てんして両端から空気を接触させて, 一方 では $\mathrm{H}_{3} \mathrm{BO}_{4}$ でモノェタノールアミンを除去して両者の 差からモノェタノールアミンを定量する方法が述べられ ている. ピリジン類は $\mathrm{BrCN}$ と benzidine とによる 比色法203) が報告されている. trinitrotoluene はアル カリ性での呈色，また nitroglycol, nitroglycerin な ぞは $\mathrm{HNO}_{3}, \mathrm{NO}_{2}$ などのきょう雑物を $\mathrm{CaCO}_{3}, o-$ toluidine で除去したのち, $\mathrm{NaOH}$-エタノール 溶液に 捕集して $\mathrm{HCl}$ で中和し, $p$-aminobenzene sulfonic acid, $\alpha$-naphthylamine, $\mathrm{CH}_{3} \mathrm{COONa}$ 添加して $530 \mathrm{~m} \mu$ で総量を測定した報告204) が見られる。そのほ か, 2-nitropropane を濃 $\mathrm{H}_{2} \mathrm{SO}_{4}$ で処理し, レゾルシ ンを用いて深赤色を比色 ${ }^{205)}$ する方法が報告された. isocyanate 類の比色定量法も述べられた. tolylene diisocyanate $の p$-dimethylaminobenzaldehyde $に$ 
よる比色法 ${ }^{206)}$, Marcali 法による比較的高濃度におけ る迅速測定法 ${ }^{207)}, \mathrm{NaNO}_{2}$ 溶液に吸収させて nitroso 化合物として比色する法, $\mathrm{HCl}$ 溶液中で diamine とし て, ジアゾ化し， $\alpha$-naphthol を作用させてアゾ化合 物にして, $496 \mathrm{~m} \mu^{208)}$ での比色法などが述べられてい る. 1,5-naphthylene diisocyanate ${ }^{209)}$ も同様な方法 で分析された。

e）その他このほかリン化合物は綿布, cotton battery, シリカゲルに試料を捕集し, $\mathrm{HNO}_{3}-\mathrm{H}_{2} \mathrm{SO}_{4}$ で酸 化し， $\mathrm{H}_{3} \mathrm{PO}_{4}$ として比色法による分析 ${ }^{210}$ が示された. tributylphosphate は $\mathrm{H}_{2} \mathrm{SO}_{4}-\mathrm{NaNO}_{3}$ で処理, 乾固 し, 残留物を $\mathrm{H}_{2} \mathrm{O}$ に溶解させてモりブデン酸アンモン による比色法211)が，また2,2-dichlorovinyldimethylphosphate はアルカリ加水分解で dichloroacetaldehyde とし，2,4-dinitrophenylhydrazine と縮合させ てその呈色を比色する方法212などが示された. dibutylphosphate はアルカリ性で $\mathrm{NH}_{2} \mathrm{OH}$ を作用させ $\mathrm{FeCl}_{3}$ で錯体としてその呈色を $580 \mathrm{~m} \mu$ で測定する微量分 析が報告213)された。そのほか, hexamethylcyclosilazane, bis(dimethylhydrazino)dimethylsilane, bis(methylamino)dimethylsilane などのケイ素化合 物は $\mathrm{K}_{2} \mathrm{~S}_{2} \mathrm{O}_{8}$ で酸化して $\mathrm{Na}_{2} \mathrm{SO}_{3}$, モール塭を加えて生 成する錯体の青色, または $\mathrm{KBrO}_{3}$ で酸化して遊離 $\mathrm{Br}$ をエオシンで発色させて比色定量 ${ }^{214)}$ される. trioxysilane, tetraoxysilane などはモりブデン酸アンモン, $\mathrm{Na}_{2} \mathrm{SO}_{3}$ による同様比色法 ${ }^{215)}$ が報告された. 大気中の 芳香族過酸化物の分析法も述べられている. 主として酸 分解を行なって，フェノール誘導体として比色法 ${ }^{216) 217) ~}$ で行なわれた。

そのほか，工業衛生的な 立場から大気中の有機化合 物の全分析法としてポーラログラフィーによる分離定 量218）が広範囲の有機化合物に適用され実用的になって きている.

\section{$14 \cdot 2$ 励染源の測定}

煙道内の排ガス中のばいじんやガスなどの測定にあた っては, サンプリングがきわめて重要な役割を演じてい る.

14·2・1 ばいじん＼cjkstart煙道の燃焼排ガス中のばいじん は口紙，ダストチューブ，インピンジャ一，小型サイク ロン，電気集じん機などで捕集したのち,ひょう量する. ばいじんのサンプリングに関しては, 吸引速度, ノズル 口径とその形状, ばいじえ粒度などの研究219)220)， ステ ンレス網を用いた $250^{\circ} \mathrm{F}$ 以上の煙道，ガス中のばいじ えの捕集 ${ }^{221)}$, 燃焼ガス分析の精度と効率に影響を及ぼ
す因子について，定性，定量両面からの検討222), ばいじ え濃度の補正についての検討 ${ }^{223)}$ ，煙突から排出する将 いじん量を光学的に測る新型測定器の考案 ${ }^{224)}$, 発生炉 ガスを主体としたタール，粉じえ，水分を定量的に測定 する装置225などについての報告がある。このほか「泣 い煙規制法」に関して，JIS に定められているもの は,ガス中のばいじん量の測定方法 ${ }^{226)}$, サンプリング用

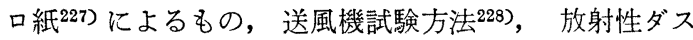
トサンプラー法229)，燃焼ガスの分析方法230)などがあ る.

14.2.2 ガス 煙道ガス中の $\mathrm{S}$ 酸化物の測定方法と しては, 排ガス温度を露点以下の温度に泠却し, 凝縮し た $\mathrm{H}_{2} \mathrm{SO}_{4}$ ミストをグラスフィルターで捕集し, $\mathrm{SO}_{2}$ は $\mathrm{H}_{2} \mathrm{O}_{2}$ を入れた吸収ビン内で酸化して中和滴定を行なう 定量法 ${ }^{231)}$, JIS の燃焼排ガス中の全酸化物分析方法 ${ }^{232}$ も同様な測定法で，この分析試薬に関係あるものとして 注 $\mathrm{H}_{2} \mathrm{O}_{2}$ 水 ${ }^{233)}$, 試薬の含量試験中滴定に関する基本事 項 ${ }^{234)}$, メチルレッド235), メチレンブルー236), イソプロ ピルアルコール237)，エチルアルコール238)などがある. 排ガス中の $\mathrm{S}$ 酸化物は $\mathrm{H}_{2} \mathrm{O}_{2}$ 水に吸収して硫酸とした のち，中和滴定する方法 ${ }^{239}$ についても述べられている。

14.2.3 自動車排気ガスこれには炭化水素, 一酸 化炭素, 酸化窒素など多種のガス成分を含んでおり, こ のうち炭化水素についてもその成分のすべてを一つの測 定器で 分析することは困難である. それらのサンプリ ング，赤外線分光光度計， ガスクロマトグラフによる 分析240) の報告, $\mathrm{NO}, \mathrm{NO}_{2}, \mathrm{CO}, \mathrm{CO}_{2}, \mathrm{SO}_{2}$, 炭化水 素, oxidants などの連続測定 ${ }^{241)}$, ディーゼル排気ガス 中の多種類の有機化合物について, 赤外線分光光度計,

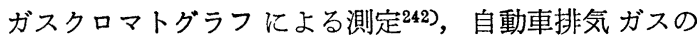
サンプリングと 分析法に 関する総説 ${ }^{243)}$ ，解説 ${ }^{244)}$ など もあり，また，自動車排気ガス中のカルボニル化合物を 2,4-ジニトロフェニルヒドラゾンとしてペーパークロマ トグラフによる確認 ${ }^{245)}$, 20\% dimethylsulfolane, 10\% diisodecylphthalate のカラムを用いキャリヤーガスと して $\mathrm{H}_{2}, \mathrm{~N}_{2}, 50 \mathrm{ml} / \mathrm{min}$ で $\mathrm{C}_{1} \sim \mathrm{C}_{6}$ の 27 種の炭化水素

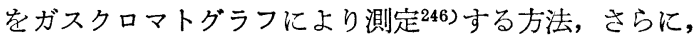
炭化水素検知器, 赤外線分光器, ガスクロマトグラフに

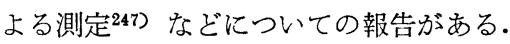

\section{交献}

1）法律第 146 号，昭和 37 年 6 月 2 日；2）政令 第 249 号, 昭和 38 年 7 月 12 日；3）厚生省・通産 省令第 2 号, 昭和 38 年 12 月 5 日；4）伊東彊自： “大気污染と制御”（応用気像学大系 11 巻), ('61), (地人書館)；5）大気污染研究全国協議会第二小委員 
会編：“大気污染の测定” ('62)，（コロナ社）； 6) 通産省・嬮生省編：“大気污染便覧”（'63），（日本公 衆衛生協会)； 7） A. C. Stern: “Air Pollution”, Vol. 1 ('62), (Academic Press, New York \& London); 8) American Conference of Governmental Institute Hygienists: "Air Sampling Instruments for Evaluation of Atmospheric Contaminants", 2nd. Ed. ('62), (1014 Broadway Cincinnati 2, Ohio); 9) P. Noss, A. Schiller, P. Wiemer: "Forschungs-Berichtes des Landes NordRhein-Westfalen ", Nr. 1041 ('61), (Westdeutscher Verlag, Köln und Opladen); 10) S. S. Griswold: "Air Pollution Field Manual", ('62), (U. S. Department of Health, Education and Welfare, Division of Air Pollution, Washington 25 , D. C.).

11) J. P. Lodge, Jr.: Anal. Chem., 33, No. 5, 3R ('61); 12) M. V. Alekseeva: Predel'no Dopustimyl Kontsentratsii Atru. Zagryazn, No. 6, 187 ('62); C. A., 58, 8344h ('63); 13) A. P. Altshuller: Anal. Chem., 35, No. 5, 3R ('63); 14) J. Lebbe: Bull. Soc. Chim. France, 462('63); 15）分化, 12, No. 11 ('63); 16) W. Jutzi: Mitt Gebiete Lebensm. Hyg., 53, 488 ('62); 17) 寺部本次：分化，12，1118 ('63)；18) 菅野三郎，小 林義隆，加藤竜夫：同上, 12，1081 ('63)；19）北川 徹三：同上，12，1074（'63)；20）荒木 峻，加藤竜 夫, 植草紀明, 久津摩淳二: 同上, 12, 1071 ('63).

21) S. N. Kimina, V. M. Polyakov: Gigiena i Sanit., 26, No. 8, 49 ('61); 22) W. Paolino: Minerva Med., 52, 1688 ('61); C. A., 58, 7290h ('62); 23) C. Tabor: Am. Ind. Hyg. Assoc. J., 23, No. 2, 145 ('62); 24) B.E. Saltzman: ibid., 23, No. 2, 112 ('62); 25) J. C. Gage: Analyst, 85, $196(' 60)$ ；26) 木村菊二: 労科, 39, 340 ('63); 27) B. J. Commins: Analyst, 88, 364 ('63); 28) E. C. Hyatt, H. F. Schulte, C. R. Jensen, R. N. Mitchel, G. H. Ferron: Proc. Intern. Congr. Occupational Health, 13th, New York, 486, ('60), (Pub. '61)；29）末永泉二，青木鈴子：公衆衛生研, 11, No. 4, 210 ('62); 30) O. Preining: Staub, 22, 456 ('62).

31) W. F. Patton, J. A. Brink, Jr.: J. Air Pollution Control Assoc., 13, No. 4, 162 ('63); 32) S. F. Yavorovskaya: Gigiena i Sanit, 28, No. 1, 36 ('63); 33) 柳沢三郎, 橋本芳一, 光沢舜 朋, 広瀬 章：分化, 12, 1069 ('63); 34) 柳沢三郎, 橋本芳一, 光沢舜朋, 白井恒雄: 同上, 12, 1070 ('63); 35) J. B. Pate, J. P. Lodge, Jr., M. P. Neary: Anal. Chim. Acta, 28, 341 ('63); 36) C. Huygen: ibid., 28, 349 ('63); 37) 秋定辰夫: 山 口医大産業医研, 9, 35 ('62); 38) 坂本 弘ほか: 産業医学, 3, 419 ('61); 39) J. Juda, K. Budzinski: Staub, 22, 466 ('62); 40) K. Guthmann: Arch. tech. Messen $\mathrm{u}$ ind. Messtech., No. 326, 71 ('63).

41）三浦豊彦，木村菊二：産業医学，4，No.3，175 ('62); 42) D. Rondéa: Air Water Pollution, 6, 353 ('62); 43) K. Leschonski: Staub, 22, 475 ('62); 44) ibid., 23, 21 ('63); 45) J. M. H. Fortuin, J. M. G. Prop: ibid., 22, 469 ('62); 46) M. Lippman, W. B. Harris: Health Physics, 8 155 ('62); 47) A. M. Fisher, Helen Christie:
Brit. J. Ind. Med., 19, 236 ('62); 48) F. Allison: Am. Soc. Testing Meter. Spec. Tech. Publ., No. 300, 130 ('61); 49) L. A. Clarenburg, L. H. Princen: Staub, 23, 34 ('63); 50) A. Loebner: ibid., 23, 371 ('63).

51）小口雄康，阿部史朗，鈴木 伸：分化，12，1063 ('63); 52) 斎藤 功, 森田茂樹, 両角 清, 小林正 武，加納多佳子：同上，12，1053('63)； 53) 斎藤 功, 森田茂樹, 両角 清, 小林正武, 加納多佳子: 同上, 12, 1049 ('63)； 54) 斎藤 功, 森田茂樹, 両角 清, 小林正武，加納多佳子：同上，12，1046 ('63); 55) 寺部本次：同上, 12, 1098 ('63); 56) 柳沢三郎, 橋 本芳一, 光沢舜朋：同上, 12, $1040\left({ }^{\prime} 63\right)$; 57) 向坊 隆，鈴木 伸，安達鏡次郎：同上， 12，1017 ('63); 58) 木村菊二：労科, $39,180(' 63)$ ；59) 大道貞男： 分化, 12, 1032 ('63); 60) T. A. Luzareva: Gigiena i Sanit., 28, 45 ('63).

61) E. A. Peregud, E. S. Stepanenko, B. S. Boikina: J. Anal. Chem. USSR, 17, 760 ('62); 62) E. V. Gernet: Novoe v Oblasti Sanit. Khim. Analiza, 25 ('62); C. A., 59, 4472e ('63); 63) M.V. Nifontova: Gigiena Truda i Prof. Zabolevaniya, 7, 58 ('63); C. A., 59, 2094d ('63); 64) A. J. Lindsey, J. R. Stanbury: Air Water Pollution, 7, 1 ('63); 65) T. K. Zhavoronkina, V. K. Zhavoronkina: Tr. Marsk. Gidrofiz. Inst. Akad. Nauk SSSR, 13, 143 ('58); C. A., 57, 3746a ('62); 66) G. V. Wheeler, W. A. Ryder, K. R. Arnold: Appl. Spectry, 16, 17 ('62); C. A., 57, 7561h ('62); 67) 伊藤庸夫, 草野一化: 工 化, 65, 318 ('62); $\quad 68$ ) M. S. Bykhovskaya: Gigiena Truda i occupational Zabolevania, 5, No. 6, 54 ('61); C. A., 56, 10510a ('62); 69) E. M. Stepanenko: Gigiena i Sanit. 26, No. 7, 66 ('61); 70) U.D. Bregvadze, M.N. Mirianashvili: Sb. Nauchn. Rabot. Inst. Okhrany Truda Vses. Tsentr. Soveta Prof. Soyuzov, No. 3, 103 ('61); C. A., 58, 7292c ('63).

71) M. D. Babina: Zh. Analit. Khim., 17, 252 ('62); C. A., 57, 2539c('61); 72) P.S. Fedrero: Pure Appl. Chem., 3, 359 ('61); C. A., 56, 3776b ('62); 73) M. D. Babina: Gigiena i Sanit., 26, No. 11, 57 ('61); 74) M. D. Babina: Zavodsk. Lab., 28, 549 ('62); C. A., 58, 7292e ('63); 75) M.S. Bykhovskaya, I. A. Orlova: Zavodsk. Lab., 27, 540 ('61); C. A., 56, 3776g ('62); 76) G. Ciuhandu, G. Krall, V. Giuran: Acta Chim. Acad. Sci. Hung, 28, 171 ('61); 77) G. A. Vasilév: Gigiena i Sanit., 27, No. 10, 54 ('62); 78) N. S. Vol'berg: Raboty po Prom-Sanit. Khim., 195 ('62); C. A., 59, 4471h ('63); 79) A. Bangsgaard, J. B. Dalgaard: Acta Pathol. Microbiol. Scand., 154, Suppl., 357 ('62); C. A., 57, 7561f ('62); 80) E. S. Gavrilets, M. V. Demchuk: Nauk Platsi L'vivs'k. Zoovet. Inst., 11, 89 ('61); C. A., 59, $12076 f$ ('63).

81) P. R. Kiff, B. R. F. Partridge: Talanta, 8, 747 ('61); 82) J. P. Lodge, Jr., E. R. Frank, J. Ferguson: Anal. Chem., 34, 702 ('62); 83) E. H. Bruins: ibid., 35, 934 ('63); 84) L. Balcarczyk, E. Lanzel: Acta Phys. Austriaca, 16, 269 ('63) ; 85) N. Ioanid, G. Bors, I. Popa, L. Armasescu, T. Stan, N. Popovici: Farmacia, 
9, 223 ('61); C. A., 56, 5076e ('62);

86) $T$. Nash: J. Sci. Instrs., 38, 480 ('61); 87) H. W. Thoenes: Brennstoff-Chem., 42, 116 ('61); 88) G. Herrmann: Z. Chem., 2, No. 2, 42 ('62); 89) L. B. Richard, J.B. Fredrick, O.H. Carlton: J. Air Pollution Control Assoc., 12, 129, 146 ('62); 90) Z. Nicola, M. G. Angela: Med. Lavoro, 53, 325 ('62); C. A., 58, 7290g ('63).

91) H. Wyszynska, K. Kosinski: Roczniki Panstuowego Zakladu Hig., 13, 377 ('62); C. A., 58, 7291h ('63); 92) W. W. Stalker, R. C. Dickerson, G. D. Kramer: Am. ind. Hygiena Assoc. J., 24, 68 ('63); 93) G. Herrmann: Chem. Tech., 15, 342 ('63); 94) H.G. Daessler, E. Ewert: Pharmazie, 18, 355 ('63); 95) D. Spencer, L. Dario, L. James: J. Air Pollution Control Assoc., 13, 429 ('63); 96) C. Huygen: Anal. Chim. Acta, 28, 349 ('63); 97) 福井昭三: 分化, 12, 1005 ('63); 98) B. T. Commins: Analyst, 88, 364 ('63); 99) Z. Nicola: Med. Lavoro, 53, 325 ('62); C. A., 58, 7290f ('63); 100) 永井迪夫, 遠藤恵子, 長谷川利雄：衛生化学, 9 , 74 ('63)

101) F. G. Edward, M. M. Raymond: J. Air Pollution Control Assoc., 13, 305 ('63); 102) L. A. Mokhov, S. A. Matveeva: Lab. Delo, 8, No. 3, 44 ('62); C. A., 57, 3746g ('62); 103) A. F. Smith, D.G. Jenkins, D.E. Cunningworth: J. Appl. Chem., 11, 317 ('61); 104) 柳沢三郎, 光沢舜朋, 広瀬章, 新井理夫: 分化, 12, 1037 ('63); 105）多田 治：労科, 37, 8 ('61)；106) 多田 治： 同上, 37, 324 ('61); 107) I. T. Cohene: Chem. Tech., 13, 170 ('61); 108) C. Costache, V. Munica: Farmacia, 9, 669 ('61); C. A., 57, 3476b ('62); 109) A. I. Bulycheva, Ts. A. Gol'dina, T. I. Sergeeva: Fiz. Khim. Metody Issledovan. Vozduskn. Sredy, Vsesoyuz. Tsentral. Nauck.-Issledovatel. Inst. Okhrany. Truda, 65 ('61) ; C. A., 56, 10509e ('62); 110) 高井宗三: 応用物理, 30,465 ('61).

111) K. M. Burrows, J. F. Horwood: Spectrochim. Acta, 19, 1 ('63); 112) K. M. Burrows, J. F. Horwood: ibid., 19, 17 ('63); 113) 鈴木武 夫, 大喜多敏一, 岩島 清: 公衆衛生研, 11, No. 1, 13 ('62); 114) G. A. Hunold, W. Pietrulla: Z. Anal. Chem., 178, 271 ('61); 115) C. R. McCully, J. F. Roesler, E. S. Gordon, J. N. Scoyoc, R. A. Corrigan: Inst. Radio Engrs. Trans., I-10, 89 ('61); 116) D. F. Adams: J. Air Pollution Control Assoc., 13, 88 ('63); 117) P. Hersch, R. Deuringer: Anal. Chem., 35, 897 ('63); 118) 多田 治, 中明賢二: 労科, 39, 595 ('63); 119) 鈴木 伸，石丸公正，樋川いく子：分 化, 12, 1065 ('63); 120) F. B. Daniel, W. B. Andrew: Anal. Chem., 35, 417 ('63).

121) A. A. Belyakov: Metody Opred. Vredn. Veshchestv v Vozdukhe Moscow, 36('61); C.I A., 59, 15846e ('63); 122) E. A. Peregud, B. S. Boikina: Zavodsk. Lab., 29, 674 ('63); C. A., 59, 9237b ('63); 123) 鈴木 汎, 大石和产: 分化, 12, 1011 ('63); 124) G. A. Lugg: Defence Ltd. Lab. Rept., 258, 8 ('62); C. A., 58, 4963h ('63); 125) J. G. Hughes, A. T. Jones: Am. Ind
Assoc. J., 24, 164('63) ; 126) F.D. Krivoruchko: Zavodsk. Lab., 27, 290 ('61); C. A., 57, 8850b ('62); 127) 荒木 峻, 加藤竜夫：分化，11，533 ('62); 128) A. P. Altshuller, J. A. Bellar: J. Air Pollution Control Assoc., 13, No. 2, 81('63); 129) M. L. Krasovitskaya, T. S. Zaporozhets, A. S. Sobolev: Gigiena i Sanit., 27, 27 ('62); 130) N. A. Klylova: ibid., 26, No. 10, 48 ('61). 131) A. Turk, J. Morrow, P. F. Levy, P. Weissman: Intern. J. Air Water Pollution, 5, 14 ('61); C. A., 56, 7653e ('62); 132) F. D. Krivoruchko: Gigiena Jruda i Prof, Zabolevaniya, 7, (7), 54 ('63); C. A., 59, $14492 \mathrm{f}$ ('63); 133) N. L. Nemirovskii, G. I. Meerovich: Tr. Leningr. Sanit-Gigien. Med. Inst., 62, 66 ('60); C. A., 57, 7564g ('62); 134) R. R. Austin: (R. R. Austin Labs., San Gabriel, Calif.), ISA (Instr. Soc. Am.) Trans., 1, 211 ('62); C. A., 57, 17009 ('62); 135) M. N. Kuz'micheva: Gigiena i Sanit., 26, No. 11, 60 ('61); C. A., 56, 5077c ('62); 136) V. A. Ivanov: Tr. Voronezhsk. Gos. Med. Inst., 29, 23 ('57); C. A., 56, 3744i ('62); 137) N. P. Anashkina: Zavodsk. Lab., 28, 669 ('62); C. A., 58, 7292f ('63); 138) M. V. Alekseeva, N.A. Krylova, V.A. Krrustaleva: Gigiena i Sanit., 28, 31 ('63); C. A., 59, 4470f ('63); 139) Y. Matsumura, R. Soda: Bull. Nat'1. Inst. Ind. Health (Japan), 4, No. 4, 44 ('60); 140) A. Saluadeo, E. Capodaglio, G. Pezzagno: Rass. Med. Ind., 1, 30 ('63); C. A., 59, 13258c ('63).

141) J. Adamiak: Chem. Anal. (Warsaw), 8, No. 4, 547 ('63); C. A., 60, 2239f ('64); 142) M. S. Bykhouskaya: Gigiena i Sanit., 28, No. 3, 48 ('63); C. A., 59, 4770g ('63); 143) G. J. Cleary: J. Chromatogr., 9, No. 2, 204 ('62); 144) B. J. Commins: Nat'l. Cancer Inst. Monograph, No. 9, 225 ('62); 145) 坂本 弘, 小島㫪 爾：産業医学， 3, No. 8, 17 ('61); 146) E. Sawicki: Nat'l. Cancer Inst. Monograph, No. 9, 201 ('62); C. A., 58, 4963a ('63); 147) K. M. Saringer: Egeszsegtudomany, 7, 25 ('63); C. A., 59, 2094c ('63); 148) D. Rondia: Arch. Belges Med. Sociale, Hyg., Med. Travail Med. Legale, $20(9 \sim 10), 567$ ('62); C. A., 59, 4470d ('63); 149) J. L. Monkman, G. E. Moore, M. Katz: Am. Ind. Hyg. Assoc. J., 23, 487 ('62); C. A., 58, 8350e ('63); 150) M. Heros, L. Amy: Compt. Rend., 255, 695 ('62).

151) J. Bonnet: Nat'l. Cancer Inst. Monograph., No. 9, 221 ('62); C. A., 58, 4693c ('63); 152) H. Wyszynska, J. Zwolinski: Roczniki Panstwowega Zakladu Hig., 13, No. 5, 503 ('62); C. A., 58, 7292a ('63); 153) A. J. Lendsey, J. R. Stanbury: Air Water Pollution, 6, 387 ('62); C. A., 58, 1849a ('63); 154) E. R. Hendrickson, C. G. Walker, V.D. Chapnerker: Am. Ind. Hyg. Assoc. J., 24, 121 ('63); C. A., 59, 3252h ('63); 155) E. Sawicki, T. W. Stanley, J. R. Hauser, H. Johnson, W. Elbert: Air Water Pollution, 7, 57 ('63); 156) W. L. Ball, G. E. Moore, J. L. Monkman, M. Katz: Am. Ind. Hyg. Assoc. J., 23, 222 ('62); C. A., 57, 11487a ('62); 157) 
S. F. Yavorovskaya: Khim. Prom., 573 ('61); C. A., 56, 6317d ('62); 158) N. V. Dmitrieva: Vestn. Tekhn. i Ekon. Inform. Nauckn. Issled. Inst. Tekhn. Ekon. Issled. Gas. Kom. Sov. Min. SSSR po Khim., 6, 36 ('62); C. A., 60, 4685b ('64); 159) A. Y. Tubina: Tr. Komis po Analit. Khim., Akad. Nauk SSSR Inst. Geokhim. i Analit. Khim., 13, 106('63); C. A., 59, 10684g ('63); 160) F. D. Krivoruchko: Gigiena Truda i Prof. Zabolevaniya, 7 (6), 63 ('63); C. A., 59, $13257 \mathrm{~h}$ ('63).

161) A. Krynska: Prace Center Inst. Ochrony Pracy, 10, 186 ('60); C. A., 58, 4963f ('63); 162) N. V. Egorov: Zavodsk. Lab., 28, 811('62); C. A., 58, 11889d ('63); 163) E. A. Peregud, B. S. Boikina: Gigiena i Sanit., 27, No. 4, 53 ('62); C. A., 57, 3745f ('62); 164) E. A. Peregud, B. S. Boikina: ibid., 27, No. 6, 49 ('62); C. A., 57, 11413i ('62); 165) D.S. Erley: Am. Ind. Hyg. Assoc. J., 23, No. 5, 388 ('62); 166) Laszlo Sujbert: Gyogyszereszat, 7, No. 7, 261 ('63); C. A., 60, 3415d ('64); 167) A. P. Altshuller, S. P. Mcpherson: J. Air Pollution Control Assoc., 13, No. 3, 109 ('63); 168) V. A. Khrustaleva: Gigiena i Sanit., 26, No. 12,39 ('61); C. A., 56, 9052a ('62); 169) E. V. Gernet: Tr. po Khim. i Khim. Tekhnol., 4, No. 3, 522 ('61); C. A., 57, 7564i ('62); 170) V. M. Hisarov: Zavodsk. Lab., 29, No. 2, 163('63): C. A., 59, 4472b ('63).

171) A. P. Altshuller, S. P. Mcpherson: J. Air Pollution Control Assoc., 13, No. 3, 109 ('63) ; 172) F. R. Cropper, S. Kaminsky: Anal. Chem., 35, 735 ('63); 173) S. S. Gurvits, T. I. Sergeeva: Gigiena Truda i Professional Zabolevaniya, 5, No. 6, 57 ('61); 174) G. Mandric: Rev. Chim. (Bucharest), 12, 503 ('61); C. A., 56, 6317h ('62); 175) E. S. Gronsberg: Khim. Prom., 508 ('61); C. A., 56, 6317b ('62); 176) Z. M. Pimenova, S. O. Khamaza: Novoe v Oblasti Sanit.-Khim. Analiza, 113 ('62); C. A., 59, 2094e ('63); 177) E. S. Gronsberg: Khim. Prom., 144 ('62); C. A., 57, 10149b ('62); 178) I. E. Selina: Uchenye Zapiski Moskov NauchIssledovatel Inst. Sanit. i Gigieny, No. 5, 35, 61 ('60); 179) M. M. Ostrouskii: Gigiena i Sanit., 26, No. 7, 64('61); C. A., 56, 37765a ('62); 180) T. G. Lipina: Novoe v Oblasti Sanit-Khim. Analiza 150 ('62); C. A., 59, 4771e ('63).

181) M. A. Klisenko: Zavodsk. Lab., 28, 930 ('62); C. A., 58, 11889e ('63); 182) I. A. Selina: Gigiena i Sanit., 27, No. 5, 41 ('62); C. A., 57, 8848h ('62); 183) T.G. Lipina: Metody Opred. Vredn. Veshchestv v Vozdukhe Maskaw Sb, 41 ('61); C. A., 59, 4471b ('63); 184) V. A. Khrustaleva: Gigiena i Sanit, 27, No. 10, 42 ('62); C. A., 58, 4962c ('63); 185) H. Collatz, H. J. Rummler: Bitumen, Teere, Asphalte, Peche, 12, 582 ('62); C. A., 58, 11886b ('63); 186) S. O. Khamaza, Z. M. Pimenova: Novoe v Oblosti Sanit.-Khim. Analiza, 145 ('62); C. A., 59, 2095a ('63); 187) I. B. Kogan, I. P. Vasiléva: Zavodsk. Lab., 28, 1428 ('62); C. A.,
59, 1028d ('63); 188) J. Roubal, J. Zdrazil: Acta Univ. Carolinae Med., 1113 ('58); C. A., 57, 7561g ('62); 189) Y.V. Dyuzheva: Uchenye Zapiski Moskov. Nauch-Issle-dovatel. Inst. Sanit. i Gigieny, No. 5, 17, 49 ('60); C. A., 56, 6319b ('62); 190) V. Sedivec: Collection Czechoslov, Chem. Communs, 25, 897 ('60); C. A., 56, 7653c ('62).

191) M. N. Kuz'micheva: Uch. Zap. Mosk. Nauch-Issled. Inst. Sanit. i Gigieny, No. 5, 27, 54 ('60); C. A., 57, 1226d ('62); 192) T. G. Lipina: Novoe v Oblasti Sanit.-Khim. Analiza, 150 ('62); C. A., 59, 4771e ('63); 193) M. N. Kuz'micheva: Uch. Zap. Mosk. Nauch-Issled. Inst. Sanit. i Gigieny, No. 5, 27, 54 ('60); C. A., 57, 1226d ('62); 194) G. S. Salyamon: Gigiena i Sanit., 28, No. 5, 50 ('63); C. A., 59, 9236a ('63); 195) G. A. Lugg: Anal. Chem., 35, 899 ('63); C. A., 59, 4469d ('63); 196) E. V. Deyanova: Novoe v Oblosti Sanit.-Khim. Analiza, 133 ('62); C. A., 59, 2094h ('63); 197) A.A. Belyakov: Tr. po Khim. i Khim. Tekhnol., 4, 778 ('61); C. A., 58, 11888a ('63); 198) K. Ascik: Polimery, 7, 332 ('62); C. A., 59, 3252e ('63); 199) M. A. Klisenko: Zh. Analit Khim., 17, 1114 ('62); C. A., 59, 1028e ('63); 200) N. D. Rozova: Novoe v Oblasti Sanit. Khim. Analiza, 173 ('62); C. A., 59, 3253e ('63).

201) L. A. Mokhov, N. S. Mareeva: Lab. Delo, 8, No. 11, 29 ('62); C. A., 58, 8350g ('62); 202) D. Williams, D. Miller: Anal. Chem., 34, No. 2, 225 ('62); 203) V. Z. Dolgopolova, R. I. Ogloblina: Sb. Nauchn. Rabot Inst. Okhrany Truda Vses. Tsentr. Soveta Prof. Soyuzov, No. 1, 103 ('61); C. A., 57, 3744i ('62); 204) 秋定 辰夫: 分化, 12, 43 ('63); 205) L.R. Jones: Am. Ind. Hyg. Assoc. J., 24, No. 1, 11 ('63); 206) B. Robinson: ibid., 23, 228 ('62); C. A., 57, 12829d ('62); 207) R. F. Skonieczny: ibid., 24, 17 ('63); C. A., 59, 1026b ('63); 208) A. Y. Tubina: Metody Opred. Vredn. Veshchesta v Vozdukhe Moscow Sb, 60 ('61); C. A., 59, 1026h ('63); 209) W. Pilz: Mikrochem. Ichncanal. Acta, 279 ('63); C. A., 58, 19619f ('63); 210) K. Y. Vengerskaya, E. G. Shelukhina: Gigiena i Sanit., 26, No. 12, 88 ('61); C. A., 56, 10509i ('62).

211) A. M. Vorob'ev, A. N. Efimova: Gigiena i Sanit., 27, No. 7, 32('62); 212) J.T. Hughes: Analyst, 88, 318 ('63); 213) W. Stanilewicz: Chem. Anal. (Warsaw), 8, 267 ('63); C. A., 59, 15844g ('63); 214) F. D. Krivorachko: Zavodsk. Lab., 29, No. 8, 927 ('63); C. A., 59, 15846h ('63) ; 215) F.D. Krivorachko: Gigiena i Sanit., 28, No. 2, 54 ('63); C. A., 59, 4470h ('63); 216) M. V. Alekseeva, E. G. Kachmar, V. A. Khrustaleva: Uch. Zapiski Moskov. Nauch. Issledovatel, Inst. Sanit. i Gigieny, No. 5〜16, 42('60); C. A., 58, 4962c ('63); 217) G. S. Saylyomon: Gigiena i Sanit., 27, No. 10, 51 ('62); C. A., 58, 4962c ('63); 218) I. B. Kogan: Novoe v Oblasti Sanit.-Khim. Analiza, 64 ('62); C. A., 59, 2093g ('63); 219) 水見康二: 安全工学, 2,185 ('63); 
220) 水見康二：分化，12，1110 ('63).

$221)$ E. A. Wolfe: Air Eng., 4, No. 12, 24, 26 ('62); 222) I. Fells, T. J. Howells, M. A. Patrick: J. Inst. Fuel, 34, 283 ('61); 223) J. L. Sullivan: J. Air Pollution Control Assoc., 12, 474 ('62); 224) P. A. E. Crosse, D. H. Lucas, W. L. Snowsill: Inter. J. Air Water Pollution, 4, 212 ('61); 225) H. Bindernagel: Technik, 17, 105 ('62); 226) JIS $Z 8808$ ('63); 227) JIS P 3301 ('56); 228) JIS B 8330 ('62); 229) JIS Z 4601 ('62); 230) JIS K 2301 ('63).

231) M. Hessink: J. Inst. Fuel, 36, 372 ('63); 232) JIS K 0103 ('63); 233) JIS K 8230 ('61); 234) JIS K 8006 ('61); 235) JIS K 8896 ('61); 236) JIS K 8897 ('61); 237) JIS K 8839 ('61); 238) Jis K 8102 ('61); 239) W. Leithe: Mikro- chim. Acta, 166 ('62); 240) W. J. King, K. Wilson, D. J. Swartz: J. Air Pollution Control Assoc., 12, No. 1, 5 ('62).

241) K. Derge: V. D. I. Z., 105, No. 11, 451 ('63); 242) R. H. Linnel, W. E. Scott: A. M. A. Arch. of Environ. Health, 5, No. 6, 616 ('62); 243) W. J. King, K. Wilson, D. J. Swartz: J. Air Pollution Control Assoc., 12, 5, 47 ('62); 244) 山手 昇：分化, 12, $1104\left({ }^{\prime} 63\right)$ ；245) E. D. Barber, J. P. Lodge, Jr.: Anal. Chem., 35, 348 ('63); 246) R. Feinland, A. J. Andreatch, D. P. Cotrupe: ibid., 33, 991 ('61); 247) J. L. Jones, E. A. Schuck, R.W. Eldridge, N. Endow, F. W. Cranz: J. Air Pollution Control Assoc., 13, 73 ('63).

\section{5 生 化学分析}

丹羽 正治 ${ }^{* 1} \cdot$ 斎藤 正行 ${ }^{* 2} \cdot$ 北村 元仕 ·吉田 光孝 ${ }^{* 3} \cdot$ 高原喜八郎 ${ }^{* 4} \cdot$ 春日 誠次 ${ }^{* 5}$

三 宅 儀・西村 敏夫 ·河野 剛 - 岩井 一義・鳥塚 完爾*6 小川俊太郎*7

$15 \cdot 1$ 生体成分

本進歩総説注前回本誌に発表されたものりの続編であ り, 1962 年および 1963 年末までの間に発表された臨床 生化学領域のおもな交献を集録した.

15.1.1 鸴籍および雑誌 Anal. Chem. 1963 年版 の展望2)には 1961 年および 1962 年に発表された 900 以上の交献が紹介され, 前回の数を 300 近くも上回り, この方面の急激な発展が伺える. この発展を反映して書 籍も新版や各種単行本が続々と刊行されている.アメリ カの臨床検査室に広く普及している次の 2 種類の単行本 が改版された。“Gradwohl’s Clinical Laboratory

*1 国立第二病院研究検査科 (東京都目黒区大原町)

*2 東京大学医学部付属病院分院（東京都交京区稚司 ヶ谷町)

*3 虎, 門病院臨床生化学科（東京都港区赤坂葵町）

*4 日本專売公社東京病院検査科（東京都港区芝赤羽 町)

*5 関東聥信病院（東京都品川区五反田）

*6 京都大学医学部内科第二講座 (京都市左京区聖護 院河原町)

*7 口- 一製薬株式会社研究所（大阪市生野区巽西足 代町)
Methods \& Diagnosis” は総ページ 2000 以上もある 広範な権威あるものであるが, 生化学関係はこのうち 300ページほどを占めている3).また“Todd-Sanford's Clinical Diagnosis by Laboratory Methods" も 1908年に初版の出たバイブル的な存在の本であり, 今回 の版のうちのかなりの部分を, 機器解説, 超微量分析, 肝機能検査, 血清酵素などの化学領域のものが占めてい る4).

臨床化学の発展に伴う新しい問題点や定量方法を集計 してある“Methods of Biochemical Analysis”の 第 11 巻5), および “Advances in Clinical Chemistry” の第 $\left.5^{6}\right) ， 6^{7}$ 巻がそれぞれ刊行された. 前者では 原子吸収分析による生体試料の分析，ガスクロマトグラ フィーによるステロイドの分離定量などが取り上げら れ, 後者では先天性代謝異常, ハプトグロビン, 各種脱 水素酵素, ブドウ糖の酵素的測定法などが扱われてい る.

超微量分析の必要性はますます高まり,この方面の書 籍も多い. “Ultramicro Methods for Clinical Laboratories”で沱写真入りで超微量用の機器, 用具 の解説, 検查方法の記載などがあり, 各章ごとの解説が 